\author{
Abstracta Iranica \\ Abstracta Iranica Revue bibliographique pour le domaine irano-aryen \\ Volume 37-38-39 | 2018 \\ Comptes rendus des publications de 2014-2016
}

\title{
Florence Jullien. « Les controverses entre chrétiens en milieu sassanide : un enjeu identitaire »
}

\section{Christelle Jullien}

\section{(2) OpenEdition}

1 Journals

\section{Édition électronique}

URL : http://journals.openedition.org/abstractairanica/44293

DOI : 10.4000/abstractairanica.44293

ISBN : 1961-960X

ISSN : 1961-960X

Éditeur :

CNRS (UMR 7528 Mondes iraniens et indiens), Éditions de l'IFRI

Référence électronique

Christelle Jullien, «Florence Jullien. « Les controverses entre chrétiens en milieu sassanide : un enjeu identitaire » », Abstracta Iranica [En ligne], Volume 37-38-39 | 2018, document 13, mis en ligne le 30 décembre 2018, consulté le 28 septembre 2020. URL : http://journals.openedition.org/ abstractairanica/44293 ; DOI : https://doi.org/10.4000/abstractairanica.44293

Ce document a été généré automatiquement le 28 septembre 2020

Tous droits réservés 
Florence Jullien. « Les controverses entre chrétiens en milieu sassanide : un enjeu identitaire "

Christelle Jullien 


\section{RÉFÉRENCE}

Florence Jullien. « Les controverses entre chrétiens en milieu sassanide : un enjeu identitaire » dans Flavia Ruani (éd.). Les controverses religieuses en syriaque. Paris : Geuthner, 2016, p. 209-238, (Études syriaques 13).

1 L'A. souligne qu'en milieu sassanide, les controverses entre chrétiens de divers courants (en particulier entre syro-orientaux et syro-orthodoxes) comportèrent une dimension identitaire très forte qui explique l'implication importante des communautés syriaques dans les débats théologiques de leur temps, perçus aussi comme des moyens de positionnement stratégique. En monde syriaque comme ailleurs, la controverse fut d'abord l'affaire d'une élite cultivée, formée à la confrontation dans un cadre ecclésial. À cet égard, le monachisme a joué un rôle important car les fondations étaient des pôles référents pour l'élaboration argumentaire et la diffusion doctrinale. $\mathrm{Au} \mathrm{VI}^{\mathrm{e}}$ et au début du VII ${ }^{\mathrm{e}}$ siècle, l'organisation de disputationes entre chrétiens à la cour de Séleucie-Ctésiphon, en présence du roi et des notabilités notamment religieuses mazdéennes, devait conduire à une formidable "médiatisation" pour les différents courants christologiques. Considérées comme un divertissement royal, ces controverses représentaient surtout, pour les chrétiens, un enjeu politique majeur en raison de leur incidence sur leur insertion dans la société, et surtout de leurs conséquences pour la survie même des Églises. L'A. analyse les éléments du discours polémique dans lequel la représentation hérésiographique, utilisant l'humour et la dérision, est utilisée afin de déconstruire l'image de l'adversaire.

\section{AUTEURS}

\section{CHRISTELLE JULLIEN}

CNRS, Mondes iranien et indien, Paris 